\title{
Leadership Behaviour of Elementary School Headmaster Christian Education Foundation School Kabaruan, District Talaud Island, Indonesia
}

\author{
Natalia Taarega Jeffri S.J Lengkong Marien Pinontoan \\ Magister Education Management Postgraduate Program \\ Manado State University, Indonesia
}

\begin{abstract}
Abtsract
This this study aims to obtain the results of analysis and description of: Principal Leadership Behavior at SD Pendidikan Foundation (YPK) Kabaruan Elementary School in Talaud Islands Regency, Factors that support the Principal's Leadership Behavior at the Kabaruan Christian Education Elementary School (YPK) in the Talaud Islands Regency, Factors that inhibit Principal Leadership Behavior at elementary school Christian (YPK) Kabaruan in Talaud Islands Regency,Efforts are being made to address the leadership behavior of the principal. This study uses a descriptive method with a naturalistic approach. Descriptive nature refers to: (1) data collected in the form of words or documents; and (2) the research report contains excerpts from the data as an illustration in providing support for what is presented. For naturalistic approaches chosen for the following reasons. The problem that the researchers examined was about things that were going on at school, with the hope that data could be collected as much as possible, while still paying attention to data quality. Data collection techniques are the most important step in research, because the main purpose of the research is to obtain data. Without knowing the data collection techniques, the researcher will not get data that meets the specified data standards. When viewed from the data source, data collection can use primary sources, and secondary sources. Primary sources are data sources that directly provide data to data collectors, and secondary sources are sources that do not directly provide data to data collectors, for example through other people or through documents. Based on the results of the research and discussion presented in chapter IV, conclusions can be drawn as follows: The Principal of the Dassar Christian Education Foundation (YPK) Kabaruan in the Talaud Islands District in carrying out his duties was more likely to use a situational leadership model. Factors that support the leadership of the principal can be seen, among others, internal factors, namely good personality, discipline, firmness and modesty. The principal has managerial skills that should be improved. The implementation of teacher supervision, and external factors, namely the location of the school, environmental conditions, community support, administration, board of teachers, parents of students and the school committee. The inhibiting factor for the leadership of school principals in implementing a situational model is that there are still teachers who feel more senior, higher class, so that they do not support the principal's thinking pattern, there are also teachers who feel that the principal is carrying out discipline in schools such as the military. teachers who are lazy because they feel there are still relatives, principals are often absent from school because of outside school-related affairs / tasks. Businesses carried out are principals who have efforts to maximize situational leadership such as seeking a personal approach to teachers in guiding, directing, motivating and understanding applicable regulations, the principal entrusts his duties to the deputy headmaster of each school. leaving school because there is an affair at the education office related to the development of the school itself.
\end{abstract}

Keywords: Teacher Performance, Managerial Abilities, Learning Facilities

DOI: $10.7176 / \mathrm{JEP} / 10-21-03$

Publication date:July $31^{\text {st }} 2019$

\section{Introduction}

Education as a conscious and planned effort to create a learning atmosphere and learning process for students to actively develop their potential to have religious spiritual strength, self-control, personality, intelligence, noble character, and skills needed by themselves, so that education can be interpreted as conscious effort and systematic to achieve a better standard of living or progress. In the development of education there needs to be a role for the principal. The Principal is a career position obtained by someone after serving for a long time as a teacher. Someone is appointed and trusted to occupy the position of headmaster must meet the criteria that are required for the position in question. To help principals in organizing schools regularly, the essence of theoretical thought is needed, such as the classical conception of organizational structure, hierarchy, authority and mechanism, coordination in the school environment. The principal also needs to understand formal organizational theory which is useful to describe the cooperative relationship between the structure and results of a school.

Wahjosumidjo, (2013: 4) argues, the essence of leadership is the participation of other people's willingness to follow the wishes of the leader. Principals as leaders must be able to: (a) Cause strong will with enthusiasm and confidence of the subordinates in carrying out their respective duties. (b) Providing guidance and directing subordinates and giving encouragement, spurring and standing in front for progress and providing inspiration in 
achieving goals.

Leadership is the art of intentionally influencing the activities of individuals or groups to achieve organizational goals. The ultimate goal of the task of leadership is to optimize all organizational potential to create healthy organizational performance so that goals are achieved effectively and efficiently. Owen, (1991:2) asserted leadership is a dimension of social relations in organizations in order to give influence between individuals or groups through social interaction. The process of interaction from one person can influence other people to think and behave in a way that is definitely desirable, this becomes a point that influences leadership, which involves deliberate practice affecting organizational behavior from others.

Knowledge of leadership is a big contribution to school principals. Historical studies to analyze leadership such as contingency approaches need to be instilled in school principals, so as to improve the quality of leadership of principals which are felt to be very important (cruisal) for the success of the schools they lead. Leadership is an important force in the framework of management, therefore the ability to lead effectively is the key to the success of the organization.

The elements inherent in leadership pertain to aspects of leadership, follower aspects, and aspects of the situation. Group elements, with regard to group norms and values, cohesiveness, relevance to goals, group expectations and group needs. Elements of the situation, with regard to organizational value variables, technological influences, task demands, and task variations.Good leadership must be able to build the life of the organization by developing a culture called superior values or "value of excellence". Leadership related to the participation of all members or followers adapts to changes in achieving individual and organizational goals, as well as actively coordinating the necessary tasks to achieve success. To optimize the main tasks and functions, the principal must appoint representatives who are able to work according to the division of labor. As leaders, principals must be able to work with and through their representatives, or what is popularly referred to as "a good leader is doing things by other people", leaders who both work with and through others, are not merely shackled by affairs technical, especially working alone almost all school assignments.

According to Usman, (2007: 284), behavioral perspectives focus on observable behavior, style of acting and acting as a way of governing, how to make decisions, how to motivate, how to communicate, how to coordinate and so on so that this view of behavior is known as one best way (one best way). Activity influencing has become the main task of a leader because it is the most important thing of a leadership system to achieve the goals of an organization.Thus a school principal can understand, anticipate and correct conflicts that occur in the school environment, principals need to learn the dimensions of social system theory (school system theory), school principals are expected to be able to analyze the school's informal life and the climate or atmosphere of the school organization.

The most important thing here is how to create an atmosphere that allows the communication process to take place. In addition, the teacher and other employees view that the results of a communication process can be carried out if each teacher has a high level of work discipline in carrying out teaching assignments. Therefore it is necessary to process a planned, systematic, and continuous discipline that enables the formation of obedience and obedience in schools towards the norms that apply in the school.

Leadership behavior applied by school leaders is a factor that can always guide, and direct and control all school activities in a more dynamic direction, especially with regard to efforts to foster and develop teacher performance in carrying out their duties. In this case the principal as the administrator of the principal must be able to empower him using available resources optimally. Furthermore, a school principal must be able to work together with other people in the school organization. As an education leader, the principal must be able to mobilize all the human potential within it, including teachers, students, and administration and society to realize educational goals. The behavior of principals in terms of leadership that occurs in schools is not yet visible and open in terms of management in various aspects of the school so that it impacts on teachers, administration and students at school. The existing conditions at SD Pendidikan Pendidikan Foundation (YPK) Kabaruan, have 9 people and 43 students, with lessons starting at 7:15 a.m. and ending at 1:00 p.m., valid from Monday to Saturday. The principal should be able to organize schools and personnel working in an efficient, conducive, effective, democratic and cooperative situation. The principal must also be able to lead professionally with the teaching staff, work scientifically, be attentive and democratic, by emphasizing the improvement of the teaching and learning process, in building quality schools.

Then, for the success of an education in school one of them is determined by the quality of the leader in this case the principal. Principal leadership can influence education in the school environment. A principal is a leader who will determine the steps of an effective education process in the school environment. But the success of a leader depends on his ability to adjust his leadership behavior to the environment and the individual characteristics of his subordinates. As revealed by Thoha (2007: 1), "An organization that will succeed or fail is largely determined by leadership. A noble expression that says that a leader is responsible for failure to carry out a job, is an expression that places the position of leader in an organization in the most important position ". This expression proves that a leader occupies a position in an organization and is responsible for the success or failure of the 
organization he leads. Based on the description, the researcher was interested in researching, with the title: "Principal Leadership Behavior at the elementary school Christian foundation school (YPK) Kabaruan in the Talaud Islands Regency".

In general, this study aims to obtain the results of analysis and description of "Principal Leadership Behavior in SD YPK Kabaruan in Talaud Islands Regency". In particular, this study aims to obtain the results of analysis and description of:

1. Principal Leadership Behavior at SD Pendidikan Foundation (YPK) Kabaruan Elementary School in Talaud Islands Regency

2. Factors that support the Principal's Leadership Behavior at the Kabaruan Christian Education Elementary School (YPK) in the Talaud Islands Regency.

3. Factors that inhibit Principal Leadership Behavior at elementary school Christian (YPK) Kabaruan in Talaud Islands Regency.

4. Efforts are being made to address the leadership behavior of the principal.

\section{Literature Review}

\section{1. basic concept of leadership}

Principal leadership is one of the processes affecting other people and that is part of running an organization with a purpose for a change, and change occurs because it is influenced by managerial which is effective and efficient in achieving certain goals within an organization.Some experts provide definitions of leadership or leadership. Stogdill (Ahmad. Sanusi and Sutikno 2009: 18), states that leadership as a management concept can be formulated in a variety of definitions depending on where the starting point of thought is.Ahmad Sanusi and Sutikno (2009: 19), argued that leadership is a process to influence and move other people effectively and efficiently to achieve organizational goals.Terry and Rueh (quoted by Kambey, 2003: 129), argued that leadership can be seen as the ability of a person or leader, to influence the behavior of others according to their desires in one particular situation.

Kambey, (2003: 130), defines leadership as a process influencing a person's activities or activities of a group of people so that they are directed towards achieving the stated goals.Dirawat, et al. (1983: 33) emphasized that "Educational Leadership as an ability in the process of influencing, coordinating, mobilizing other people who have to do with the development of the science of education and the implementation of education and teaching so that activities can be run more effective and efficient in achieving educational and teaching goals.

Hadari Nawawi, (1984: 82) added that "Educational leadership is the process of moving, influencing, motivating and directing people in educational organizations / institutions especially to achieve the goals that have been formulated".Leadership, of course, is very important for the running of an organization because if an organization runs without a good element of leadership from its members as well as from its organizational leaders, then any problems that arise in the running of the organization will be difficult to solve quickly and efficiently, which results in the goal and the satisfaction of the achievement goals is very low.A leader must have the expertise and social ability to become a good and responsible leader and a leader who can truly carry out his responsibilities, exercise control and control so that goals within the organization can be achieved.From the understanding of the experts above, it can be concluded that leadership is not a mere position that gives a person the qualifications to lead. More than that, leadership is the ability possessed by someone to influence the opinions, attitudes, and behavior of others according to leadership. This means that a person who is able to direct or influence others in one position can function as a leader.

Leadership functions to direct, move, join in working together while being an example, encouraging followers to be willing to use their willingness to work optimally to support the achievement of organizational goals. But to formulate what is meant by leadership functions is difficult, as difficult as providing a definition of leadership itself.This difficulty is because leadership attracts the attention of experts to examine it, thus giving birth to different leadership. Meanwhile, the following definition gives an indication that:

1) A leader functions to move other people so that the other person consciously wants to do what the leader wants. 2) A leader functions as a person who is able to create change effectively in group performances. In the opinion of experts, are as follows.From the description above it can be concluded that the functions or tasks that must be carried out by the leader or commonly called leader functions. To better understand the meaning of leadership, here are some theories about leadership:

1. Contingency Theory of Fred Fiedler (in Kambey 2003: 144)This theory concludes that to be an effective leader, one needs to adjust his leadership style (leadership style) to the situation he faces (life cycle). So in other words, someone's leadership is permanent, so to get high achievements, adjustments are needed.

2. The Life-cycle Theory of Paul Hersey and Keneth Blanchard, Fiedler, Hersey and Blanchard (in Kambey 2003) suggests that leadership behavioral strategies must be situational; because the success of the leader depends on the level of maturity (level of maturity) of his followers, because they are the ones who accept or reject the leader.

3. Support Theory.According to this theory the followers must try as hard as possible, and work passionately, 
while the leader will lead and guide them best through certain policies.

In the opinion of experts, are as follows:(Stoner, 1982: 468) For groups to operate effectively, a leader has two main functions, namely:

1) Group maintenance function or social function includes leaders helping groups operate more smoothly, leaders give approval or complement other group members, for example bridging groups that are at loggerheads, paying attention to group discussions.

2) Task related or problem solving function, in this function the leader gives advice in solving problems and contributing information and opinions. There are four important tasks for a leader.

1) Defining the Mission and Role of Organizations (involves the definition of institutional organizational missions and roles).The mission and role of the organization can only be formulated or defined as well as possible, if a leader first understands the structural assumptions of an organization, namely:

a. The existence of the organization especially to achieve the stated goals

b. In the life of an organization there is one structure that is right for goals, environment, technology, and participants / members.

c. The existence of the organization especially to achieve the stated goalsd. The structure can be designed systematically and appropriately implementede. Organizational problems usually reflect the existence of structures that are not fixed and can be solved through a reorganization designf. Coordination and control is achieved best through the implementation of impersona authority and regulations

2) A leader is an embodiment of purpose. The purpose of an organization is to produce an item or service. The manifestation function of organizational goals means that a leader in addition to understanding the purpose of the organization's establishment also understands the characteristics of the organization as an open system.Although people are human resources of the organization, but the organization is more than human beings themselves. The organization also includes: machine tools, equipment, facilities, facilities and funds that enable people to produce goods or services.As an open system, organizations transform humans and physical resources that are accepted as inputs from their environment into goods and services which are finally returned to the environment as consumers 3) Maintaining the integrity of the organization (to defend the organization integration) Leaders represent organizations to the public and to their staff, just as leaders try to invite subordinates to follow decisions so that these functions can be carried out. Some key assumptions that leaders need to understand:

a. Organizations and humans need each other. Organizations need thoughts, ideas, energy, and potential, given by humans.

b. Organizations are held to help humanitarian needs, and humans are not there to help the needs of the organization.

c. If there is a match between the situation between the individual and the organization, both of them will get benefits. Individuals are able to carry out work that is meaningful and satisfying.

4) The last task of a leader is to control internal conflicts that occur within the organization (the ordering of internal conflict).In the life of a modern organization, conflict cannot be avoided. The organization has another profile that includes a normative order (normative order), the level of the rule (authority ranks) system communication and system incentives. It is also necessary to acknowledge that the organizational pattern is an open system so that it opens up the possibility of various kinds of perceptions in terms of organizational performance. In this case it can be a source of causes of conflict.For a leader must try to understand and learn aspects related to conflict, such as the process of conflict, characteristics of conflict, sources of conflict, the level of conflict, conflict management styles, and the role of leadership in dealing with conflict.

\subsection{Behavior and leadership theory}

Leadership behavior is specific actions of a leader in directing and coordinating the work of group members. Hasibuan, (2000: 167) says leadership behavior in carrying out leadership tasks includes the following activities:Take decisions, develop imagination, develop loyalties of followers, initiators, activate and procure plans, utilize human resources and other sources, carry out controls and corrections to mistakes, give awards, delegate authority to subordinates, implement decisions by encouraging to his followers.Human behavior can occur due to human stimulation that comes from the strengths or values possessed by it. Understanding of human behavior should understand the dynamics of the behavior, the structure of perception and cognition, and reorganization of human cognition. When observed and connected with leadership it is clear that leadership behavior can be changed or formed. The desire of a leader to do something or make a change for example will be able to change the behavior of the leader. The existence of requests especially instructions or higher orders will be able to change leadership behavior.

Basically, a person's behavior is difficult to observe. Bishop, (1970: 111) states that human behavior cannot be described. Whereas Djawad Dahlan, (1982) has the assumption that a person's behavior can be predicted more precisely when his attitude is known. There are two human behaviors, namely: (1) types of behavior that cannot be understood (overt), and (2) types of behavior that can be understood (covert). Leadership behavior can be 
observed by looking at the actions taken by the leader as in communicating with the principal can be observed by looking at the actions taken by the principal in daily activities. There are several factors that influence the leadership behavior of principals in school management, including education and training, experience, personality, and socio-cultural environment.

Personality is an activity of someone who can reflect his behavior in acting and doing something, it is clear that the personality of an educational leader will influence his behavior in conducting school management. Therefore, an education leader is required to have personality traits, such as fair and honest, courageous and decisive, generous, and friendly. The socio-cultural environment will influence the leadership behavior of the principal in managing the school. Because basically the school and the surrounding environment are one unit that influences each other, so that the school can meet the needs of the surrounding environment, the behavior of the principal in managing the school is a very decisive thing in achieving goals. The quality of leadership can only be achieved if within each leader there is a deep awareness and understanding of the meaning of leadership with all aspects such as principles, various requirements and leadership functions, so that leaders are able to develop skills and realize the various leadership functions needed.

As a leader, the principal in appointing representatives in the curriculum field should evaluate the abilities and performance of teachers who are experienced in the curriculum. Leadership has related characteristics so that it becomes a unit that is owned by a leader and who he leads. The application of leadership is largely determined by the work situation or the state of the members, subordinates and supporting resources of the organization. Effective leaders must learn from mistakes in the past and try to improve in a wise way and provide opportunities for subordinates to provide criticism and suggestions for improvement. The principal, in carrying out his duties as a leader, must realize his actions in answering several questions with which he determines his success as a leader. Effective headmaster indicators can be observed from three main points as follows:

1) Commitment to the school's vision in carrying out its duties and functions

2) Making school vision a guideline in managing and leading schools

3) Always focus its activities on learning and teacher performance in the classroom.

The nature approach views leadership as a combination of visible traits. This approach assumes that the leader must have some excellent qualities that are born from birth. In other words the leader is born. According to Edwin Ghiselli (quoted by Handoko, 2001: 297) certain characteristics that appear to exist in leadership are as follows:

1) Ability as a supervisor

2) Having a need for achievement at work

3) Intelligence

4) Firmness

5) Confidence

6) Initiative

According to Stoner et al. (1992: 163) suggest that: although measurement of personality traits may at some time be accurate enough to isolate the characteristics of leaders, the evidence so far illustrates that people who have appeared as leaders do not have a clear set of traits that distinguishes it from leaders. They further said that most other studies in this field also found that effective leadership does not depend on certain traits, but rather on how well the leaders' characteristics match their needs and situation. It is very clear to us that the situation and conditions of the organizational environment greatly influence the description of the characteristics of leaders in controlling staff and organizations. That is why an adaptation of the traits adopted by the leader with the existing situation and conditions is needed. But the disadvantage of this approach is that it is difficult to get a generalization of leadership traits that can apply to other people. Although this trait approach has been criticized for implementation, this approach is the basis for the emergence and development of other approaches such as the leader behavior approach by interacting with his staff.

\section{Research Method}

This study uses a descriptive method with a naturalistic approach. Descriptive nature refers to: (1) data collected in the form of words or documents; and (2) the research report contains excerpts from the data as an illustration in providing support for what is presented. For naturalistic approaches chosen for the following reasons. The problem that the researchers examined was about things that were going on at school, with the hope that data could be collected as much as possible, while still paying attention to data quality.

Qualitative research method is a research method that is used to examine the object's natural condition, (as opposed to an experiment) where the researcher is a key instrument, the technique of data collection is triangulated (combined), data analysis is inductive, and qualitative research results are more emphasize the meaning rather than generalization.Natural objects are objects that are as they are, not manipulated by the researcher so that the conditions when the researcher enters the object, after being in the object and after exiting the object is relatively unchanged. In qualitative research, researchers become instruments. Therefore in qualitative research the instrument is a person or human instrument. Criteria for data in qualitative research are definite data. Definite data 
is the actual data that occurs as it is, not data that is merely visible, spoken, but data that contains the meaning behind the visible and spoken.

Two data sources that provide different data, then the data is uncertain. Data collection with observations and interviews that produce different data, then the data is also uncertain. If the data obtained is still in doubt, and has not yet obtained certainty, then the research must still be continued. So data collection with triangulation technique is data collection that uses various sources and various data collection techniques simultaneously (together), so that certain data can be obtained.

This approach emphasizes the breakdown of observed phenomena and complex meanings that surround a reality. Thus the research report will contain excerpts of data to illustrate the delivery of the report. Bogdan and Taylor (quoted by Moleong, 2006: 4), suggest that a qualitative approach in the form of written or oral words in people and observable behavior. Moleong, (2006: 4) suggests that qualitative research is research that produces analytical procedures that do not use statistical analysis procedures or other qualitative methods of data only through interviews, recordings, photographs, and report notes. Therefore the role of research is very important in this study, namely how to establish a natural relationship between researchers and the subjects studied in the field.

Before the research takes place the researcher prepares a temporary design as the initial guide to the study while setting the desired focus. Design preparation is called temporary, because it is possible to make improvements, changes, and adjustments, with facts found in the field. This is justified by Moleong (2006) who states that qualitative research methods are more easily adapted, can present the nature of the relationship between researchers and research subjects directly. In addition, the method is more sensitive and can adjust to a lot of sharpening together the patterns of value faced. In compiling the design of this study, the researchers took steps based on the views of Bogdan and Biklen (quoted by Nasution, 1992: 31), namely:

(1) determining the focus of research, namely principals' leadership behavior,

(2) determining the qualitative-naturalistic research paradigm,

(3) looking for theories that will guide and direct research such as Leadership theories, and relevant theories and general theories,

(4) determine the data source and location of respondents,

(5) determine the research instrument in the form of interview guidelines, plans interviews and documents,

(6) preparing plans for data collection and recording, data analysis plans, logistical plans, plans to achieve a level of trust in the correctness of research, and plans for writing and completing research.

This research begins with the research flow of thinking, namely the steps of thinking carried out by the researcher reviewing the problems that have been determined in the past. Departing from the problem researchers entered the research subject by applying a qualitative armed with data collection signs that will be further developed in the field. Furthermore, researchers are involved with the subject of research, noting events that are seen and communicating with various parties who are the subject of research.The collected records are selected and sorted, then set as research data. Furthermore, the collected data is processed by separating and merging based on similarities and differences in the character of the collected data (categorization) then analyzed and interpreted by applying the theories set out in chapter II as analytical knives. The location of this study was the Kabaruan School Christian Education Foundation (YPK) in Kabaruan Subdistrict, located in Kabaruan Timur Village, Kabaruan District, Talaud Islands Regency, North Sulawesi Province.

Data collection techniques are the most important step in research, because the main purpose of the research is to obtain data. Without knowing the data collection techniques, the researcher will not get data that meets the specified data standards. When viewed from the data source, data collection can use primary sources, and secondary sources. Primary sources are data sources that directly provide data to data collectors, and secondary sources are sources that do not directly provide data to data collectors, for example through other people or through documents.

Analysis of data in qualitative or naturalistic research as revealed by Moleong, (2006: 190), data and information obtained in this study through observation techniques, waancara, documentation listed in the field notes were immediately analyzed. Data analysis and interpretation continues throughout the research procedure. Data analysis in qualitative research, carried out at the time of data collection takes place, and after completion of data collection in a certain period. At the time of the interview, the researcher had analyzed the answers of the interviewees. If the answers interviewed after being analyzed are not satisfactory, the researcher will continue the question again, to a certain extent, obtained data that is considered credible. Miles and Huberman, (1984), suggest that activities in qualitative data analysis are carried out interactively and take place continuously until complete. Activities in data analysis, namely data reduction, data display, and conclusion drawing / verification.

\section{Result and Discussion}

4.1.Description of the object of research

The Christian Education Foundation (YPK) Elementary School of Kabaruan Talaud Islands Regency began construction in 1964, then began operations in 1965 located in Kabaruan Timur Village, Kabaruan District, Talaud 
Islands Regency. This school was founded on the initiative of all villagers with evidence of raising funds to buy land of approximately 1 hectare as the location of the establishment of a school building. This idea arose because seeing children who were 6-12 years old had difficulty in school because there were no elementary schools in the village. Since it was inaugurated in 1965 until now there has been a change of headmaster as follows:

$\checkmark \quad$ 1965-1973 led by Mr. S. Mamarodia, S.GA

$\checkmark$ 1973-1980 led by Mr. H. J. Matei, S.GA

$\checkmark$ 1980-1988 led by Mr. A. P. Manoy, S.G

$\checkmark$ 1988-2004 led by Mr. O. Saraung, S.Pd

$\checkmark \quad$ 2009-2010 led by Mrs. J. Manoy, A.MA

$\checkmark \quad$ 2004-2009 and 2010-2018 led by Mr. J. Tehamen, S.Pd

$\checkmark 2018$ until now led by Ibu Oktavia I. Bunaen, S.Pd

1) School Vision, Mission and ObjectivesVisionThe realization of educated, skilled, and independent people based on faith and piety. Mission: Prepare a generation that has potential in the field of science and technology.b. Forming active, creative, innovative human resources to develop optimally in accordance with the times.c. Give skills to live independently.d. Growing discipline, and responsible for all school members. Aim of study:

a. Students have faith and fear the Almighty and noble God.

b. Students are physically and mentally healthy

c. Students have the basics of knowledge, abilities and skills to continue their education at a higher level.

Students The Christian Education Foundation Elementary School (YPK) Kabaruan Talaud Islands Regency is a formal organization including lines and staff. The head of the leadership was held by the headmaster and assisted by a deputy principal, 1 student in the field of curriculum, people in the field of curriculum, people in the field of infrastructure and facilities, and people in public relations and 6 homerooms. Have discipline, creativity, skill, and are responsible for being able to develop themselves continuously.

\subsection{Headmaster leadership behavior}

Principal's leadership behavior is one of the problems raised here, so here it will be seen as what the leadership behavior of the principal at SD Pendidikan Foundation (YPK) Kabaruan Elementary School in Talaud Islands Regency, researchers use observation, interview, and documentation to know and understand the principal's leadership behavior.

From the results of interviews with the principal and also the staff of teachers and students (OSIS), it can be explained that the principal is able to create an atmosphere of good cooperation with the teachers, also always sees the teachers as having the ability and competence that are very supportive in carrying out their duties. The principal also provides an opportunity for all teachers I to continue to work and improve their knowledge continuously. The principal also cooperates with all parties that have been interviewed, there is unity and mutual agreement in every decision making.

The following are excerpts of interviews with the principal:"In giving assignments to teachers, I always see and adjust to the potential they have, so that they carry out their duties each has a sense of responsibility, so that their work is also good. Every time there is a workshop or training I direct all teachers to join. and if anyone does not come along, I suggest that they ask the teachers who have participated, so that there are no more teachers in this school who miss information or miss the development of science. I also often advise teachers to learn to operate a computer. so as to facilitate the making of learning tools such as Learning Plans and Programs and others.

From the interview above, it can be implied that the headmaster is able to establish good communication and cooperation with all parties so that there is a sense of enthusiasm from the residents to cooperate with the school.The head of the elementary school of the Christian Education Foundation (YPK) Kabaruan in the Talaud Islands Regency apparently has a delegative function which is the main principle of leadership, this can be seen by the division of tasks to 9 teachers and 2 administrative people. Each teacher has different tasks according to the skills and knowledge they have so that this becomes an expectation to achieve school goals. In solving problems the school principal always asks for opinions and gives trust to the vice principal and teachers. When the problem can be solved, the teachers will feel satisfied, so there will be motivation from themselves to continue working in the execution of tasks and able to solve their own various difficulties.

\subsection{Factors that support Principal Leadership Behavior}

\section{a. Principal Internal.}

Factors Internal making observations and interviews, researchers use various indicators that have a relationship with personality competencies which are used as a benchmark for conducting interviews with Teachers, Administration, Students and School committee administrators about the nature and personality of the Principal. The indicators in question include discipline, good morals, honesty, modest, assertive, integrity, openness, a strong will to develop themselves, the ability to lead. Most give a good assessment of the principal.

b. School Environment External. 
FactorsExternal factors that have been investigated by researchers related to this research are the physical condition of the school, the state of the school environment and the surrounding community, the support of the teachers, the committee, the parents of the students. The school's teachers and administrative staff support the leadership of the school principal because, there are changes and developments in the Kabaruan Christian Education Foundation (YPK) in Talaud Islands District including the construction of a new Language Laboratory which was completed in December, the school environment it's well-organized and clean. The following is an interview with several teachers:"Since the principal of this school is leading here there have been many changes, for example, asking one of the parents to cut grass in the school every 3 months, holding a clean Friday program conducted by teachers with students, without exception, so that the environment the school is clean and neat

Leadership is a function of groups, not individuals. We talk of individuals as leaders, but leadership occurs from two or more human interactions. The process of interaction of one person can influence other people to think and behave and ways that are definitely desirable, this being the second key point that influences leadership where involving gaps to practice affects organizational behavior from others.Principal leadership can also be successful because of supporting factors such as; the principal's background, good personality, knowledge and skills possessed to manage and cultivate the school, the self-motivation to continue working, and the ability to interact socially with the surrounding community.In managing the school, a leader has a very large responsibility, because the principal is the driving force that determines the policy objectives to be taken. The principal as the manager and person in charge of an educational institution is always required to improve the effectiveness of his performance. In order to be able to reach an effective school the principal must be able to open up, be willing to give and share with the staff of teachers and employees so that they can create an atmosphere that is intimate, safe, peaceful and at work.

\subsection{Factors that hinder the Principal's Leadership Behavior}

From the interviews, it was revealed that the leadership of the principal did not always run smoothly, there were also teachers who did not like Situational leadership applied by their superiors, for example. (1) Lack of teacher knowledge about the prevailing leadership model, because they only became civil servants and the first placement was at the Kabaruan Primary Education Christian Foundation (YPK) in Talaud Islands District, (2) there was a teacher who felt he was more senior, his group was higher, and feel more experienced, (3) there are also teachers who feel that the principal is a close relative, so they are not afraid of the principal.

Mulyono (2008: 144) explained that "the role of the principal is very much needed to manage human beings within the school organization, including having the right strategy to manage conflict. The principal must be at the forefront and measure success". Based on the data found in this study there are also factors that hinder the leadership of the principal such as the nature of the teacher who feels more experienced, the higher group of principals so that they do not follow the conditions set by the principal, there are differences in responses from the teacher regarding the principal's situational leadership model.

Teacher who was lazy to know because there was a kinship relationship, there was a delay in the teacher coming to school and a delay in making learning devices, but with these obstacles the principal continued to try the best solution for the smooth management process at school, the principal continues to provide motivation and direction to his subordinates.Principals often leave school because of external assignments such as going to the education office for the development of the school itself, but the principal gives authority to the deputy headmaster to replace the temporary principal's assignment, but any differences that occur with the principal become a motivation to continue be the best and continue to develop themselves so that the situational leadership that they do will run better.

A situational leader must be able to show himself as an agent of change both in the internal and external environment of the school so that it can be an example and role model for teachers, administration, students and the community in the surrounding environment.In this study, the data collected by researchers shows that principals have efforts to overcome any obstacles that occur in their leadership processes, such as approaching the heart of hearts, giving understanding to teachers who feel senior and lazy to know, and continue to provide motivation.

When there are teachers who do not understand the leadership model and want to leave the school environment before the main teaching task has not been completed, the principal will provide understanding and understanding of the responsibilities and regulations that apply.The school principal provided understanding and understanding that there was no element of intentions on his part when he was rarely in school because of carrying out outside duties which were still related to school affairs, and the assignment was temporarily handed over to the vice principal.

The principal is never tired of also giving warnings, directions, guidance to teachers who are still late in arriving at school to carry out responsibilities in accordance with the specified time.The principal of the Kabaruan Basic Education Christian Foundation (YPK) in the Talaud Islands District in carrying out situational leadership made many changes to both the school environment and the personality of his subordinates, although there were 
still some obstacles faced but with good skills and personality from the principal. these obstacles can be overcome.

\section{Conclussion}

Based on the results of the research and discussion presented in chapter IV, conclusions can be drawn as follows: 1. The Principal of the Dassar Christian Education Foundation (YPK) Kabaruan in the Talaud Islands District in carrying out his duties was more likely to use a situational leadership model.

2. Factors that support the leadership of the principal can be seen, among others, internal factors, namely good personality, discipline, firmness and modesty. The principal has managerial skills that should be improved. The implementation of teacher supervision, and external factors, namely the location of the school, environmental conditions, community support, administration, board of teachers, parents of students and the school committee. 3. The inhibiting factor for the leadership of school principals in implementing a situational model is that there are still teachers who feel more senior, higher class, so that they do not support the principal's thinking pattern, there are also teachers who feel that the principal is carrying out discipline in schools such as the military. teachers who are lazy because they feel there are still relatives, principals are often absent from school because of outside schoolrelated affairs / tasks.

4. Businesses carried out are principals who have efforts to maximize situational leadership such as seeking a personal approach to teachers in guiding, directing, motivating and understanding applicable regulations, the principal entrusts his duties to the deputy headmaster of each school. leaving school because there is an affair at the education office related to the development of the school itself.

\section{References}

Ahmad, Sanusi dan Solary Sutikno. (2009) Kepemimpinan Sekarang dan Masa Depan. Cetakan Pertama. Pnospeet. Bandung.

Bishop. (1970). Kunci Menuju Sukses Dalam Manajemen dan Kepemimpinan. Indonesia Publishing House.

Dahlan, Djawad. (1982). Ciri-ciri kepribadian siswa dikaitkan dengan sikapnya terhadap jabatan guru. bandung PPS-IKIP.

Dirawat. Dkk. (1983). Pengantar Kepemimpinan Dalam Rangka Inovasi Pendidikan Pertumbuhan Jabatan Guru. Jakarta : Alda.

Esterberg, Kristin G. (2002). Qualitative Methods Ins Social Research. New York

Fiedler. (1967). Kepemimpinan Era Modern. Cetakan Kedua. Jakarta: Yayasan Kanisius.

Handoko H. (2001). Manajemen. PT. BPFE. Yogyakarta.

Harold, Koontz dan Heinz Weihrich. (1988). Manajemen. Mc. Graw Hill. New York.

Harsey, P. and Blanchard K. H. (1996). Management and Organizational Behavior. Englewood Cliffs. NJ: Prentice-Hall.

Hasibuan H M. (2000). Manajemen Sumber daya Manusia, STIE YKPN. Yogyakarta

Hersey and Blanchard. (1998). Kepemimpinan Kepala Sekolah dalam Mengembangkan Budaya Mutu. UPI, Tasikmalaya.

Kewo, C. L., \& Afiah, N. N. (2017). Does Quality of Financial Statement Affected by Internal Control System and Internal Audit?. International Journal of Economics and Financial Issues, 7(2), 568-573.

Kambey, Daniel C. (2003). Landasan Teori Administrasi Manajemen, Sebuah Industri. Ganesa Manado : Tri Ganesa Nusantara.

Koonz, \& Weihrich, (1988)

Lincoln and Guba. (1985). Naturalistic Inquiry. Sage Publication. New Delhi.

Meity Sukmawati, (2009). Gaya Kepemimpinan Kepala Sekolah Sma Muhammadiyah 3 Tangerang. Program Sarjana. Universitas Gunadarma. TESIS.

Miftah Toha. (2007). Kepemimpinan Dalam Manajemen. Jakarta: PT. Raja Grafindo Persada.

Miles M. B dan Huberman A.M. (1984). Analisis Data Kualitatif. Universitas Indonesia. Jakarta.

Moleong, L.J. (2006). Metodologi Penelitian Kualitatif. PT. Remaja Rosdakarya. Bandung.

Nasution (1992), Metode Penelitian Naturalistik Kualitatif, Penerbit Tarsito, Bandung.

Nasution H. M. N. (1996). Manajemen Transportasi. Ghalia Indonesia. Jakarta

Nawawi, Hadari. (1984). Administrasi Pendidikan, Jakarta: Gunung Agung

Owens, G. Robert. (1991). Organizational Behavior In Education London. New Jersey: Englewood Cliffs. Praction-Hall Inc.

Robbins, S.P. (2002). Perilaku Organisasi. PT. Prehalindo. Terjemahan Jakarta.

Stoner, james A.F. 1982. Management. Prestice Hall.

Stoner, james A.F. 1992. Management. Jakarta Erlangga.

Subiyakto, Kartina S. R. (2014). Analisis Gaya Kepemimpinan Lurah Batu Ix Kecamatan Tanjungpinang Timur. Universitas Maritim Raja Ali Haji Tanjungpinang. Tanjungpinang.

Thoha, (2007). 
Usman, Nasie. (2007). Manajemen Peningkatan Kinerja Guru. Mutiara Ilmu. Bandung

Wahjosumidjo. (2013). Kepemimpinan Kepala Sekolah: Tinjauan Teoritik dan Permasalahannya. Jakarta: PT. Raja Grafindo Persada.

Yuan, Ihsan (2011) "Analisis Gaya Kepemimpinan Fauzi Bahar Sebagai Walikota Padang dalam Penyelenggaraan Pemerintahan”. Universitas Andalas Padang. 